$y$

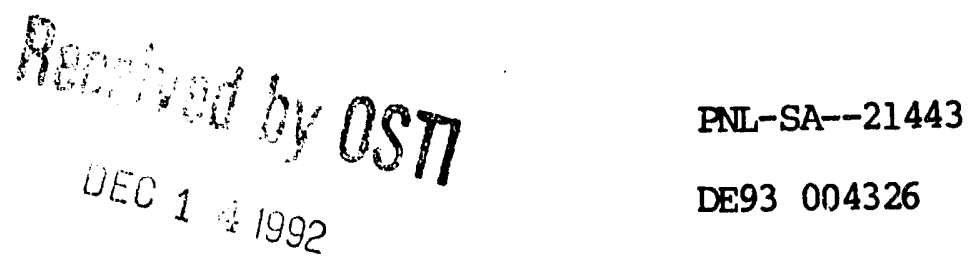

SYNTHESIS AND REACTIVITY OF ULTRA-FINE COAL LIQUEFACTION CATALYSTS

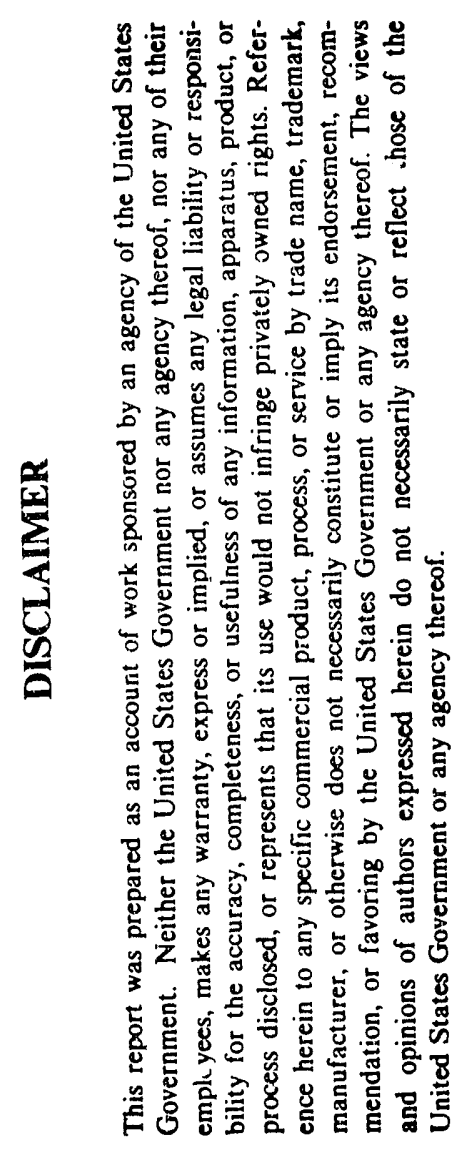
J. C. Linehan
J. L. Fulton
R. M. Bean
D. W. Matson
J. G. Darab

October 1992

Presented at the

US/Japan Technical Workshop

October 11-14, 1992

San Francisco, California

Prepared for

the U.S. Department of Energy

under Contract DE-ACO6-76RLO 1830

Pacific Northwest Laboratory

Richland, Washington 99352 


\title{
Synthesis and Reactivity of Ultra-Fine Coal Liquefaction Catalysts
}

\author{
John C. Linehan, Dean W. Matson, John L. Fulton, \\ Roger M. Bean, John G. Darab \\ Pacific Northwest Laboratory 1 \\ P.O. Box 999 \\ Richland, WA 99352
}

\begin{abstract}
The Pacific Northwest Laboratory is currently developing ultra-fine iron-based coal liquefaction catalysts using two new particle production technologies: (1) modified reverse micelles (MRM) and (2) rapid thermal decomposition of solutes (RTDS). These methodologies have been shown to allow control over both particle size (from $1 \mathrm{~nm}$ to $60 \mathrm{~nm}$ ) and composition when used to pr aduce ultra-fine iron-based materials. Powders produced using these methods are found to be selective catalysts for carbon-carbon bond scission using the naphthyl bibenzylmethane model compound, and to promote the production of THF soluble coal products during liquefaction studies. This presentation will describe the materials produced by both MRM and the RTDS methods and will summarize the results of preliminary catalysis studies using these materials.
\end{abstract}

\section{Introduction}

The development of an economical method for coal liquefaction could greatly reduce world dependence on limited petroleum resources. Major efforts aimed at improving the economic viability of coal liquefaction as a source of liquid fuels have been aimed at maximizing the efficiency of catalysts used in the process. The use of ultra-fine catalyst particles having large specific surface areas improves catalyst site availability, and the high mobilities afforded by the ultra-fine particle size provides for maximum catalyst dispersion in the coal matrix. The use of lowcost catalyst materials (e.g., iron) can also eliminate the need for expensive catalyst recovery steps in the liquefaction processes. Recent publications have demonstrated the catalytic coal liquefaction properties of inexpensive iron-based catalysts. ${ }^{2-7}$ We present our recent work on developing two new methods for the production of iron-based coal liquefaction catalysts.

\section{Experimental}

The modified reverse micelle (MRM) and the rapid thermal decomposition of solutes (RTDS) processes have been described previously. 8,9 Both methods are suitable for scaling up to produce kilogram quantities of catalyst materials. Initial catalyst screening was performed using the naphthyl bibenzylmethane model compound. 10 Coal liquefaction studies were performed using the Wyodak and Blind Canyon Seam Argonne premium coals. The coal (1.2 g), iron-oxide catalyst precursor $(0.01 \mathrm{~g})$, and sulfur $(0.01 \mathrm{~g})$, were loaded into stainless steel tube reactors with $2 \mathrm{ml}$ of tetralin and 800 psi hydrogen. The vessels were placed in an aerated sand bath at the selected temperature for the desired time. The resulting product was extracted with tetrahydrofuran, with the insoluble residue being used to calculate the liquefaction yield. The THF extract was reduced in volume and precipitated with pentane to yield the amount of pentane solubles.

\section{Results}

Representative iron-containing materials produced using the MRM and RTDS processes are shown in Table I. A range of iron-oxide phases were obtained from the MRM method by adapting standard aqueous preparations.11 The materials produced using the MRM method range in size from $1 \mathrm{~nm}$ up to tens of nanometers depending upon the phase produced and reaction conditions. 
Table I

Materials Produced Using Modified Reverse Micelles and Rapid Thermal Decompsition of Solutes Methods
Product
Crystallite Diameter (nm)
Surface Area
XRD TEM Mossbauera
BET $\left(\mathrm{m}^{2} / \mathrm{g}\right)$

\begin{tabular}{|c|c|c|c|c|}
\hline \multicolumn{5}{|c|}{ MRM Produced } \\
\hline $\begin{array}{l}\text { 2-Line Ferrihydrite } \\
\text { (Proto-Goethite) }\end{array}$ & $<<10$ & $1-10$ & $<5.5$ & $153-280$ \\
\hline Goethite & 10 & -- & --- & --- \\
\hline Lepidocrocite & 22 & --- & --- & --- \\
\hline Magnetite & 3 & --- & $<8.5$ & -- \\
\hline Maghemite & 12 & --- & $\cdots$ & --- \\
\hline Iorn-Sulfide & 10 & $1-20$ & -- & --- \\
\hline \multicolumn{5}{|c|}{ RTDS Produced } \\
\hline 2-Line Ferrihydrite & $<<10$ & $1-10$ & $<8.5$ & --- \\
\hline 6-Line Ferrihydrite & $<<10$ & -- & $\cdots$ & --- \\
\hline Hematite & $<<10$ & $2-10$ & $<8.5$ & 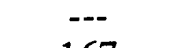 \\
\hline Hematite & 11 & $10-20$ & $\begin{array}{l}52 \%>8.5 \\
17 \%<5.5\end{array}$ & 167 \\
\hline Hematite & 23 & $20-70$ & $90 \%>8.5$ & $-\cdots$ \\
\hline
\end{tabular}

a) The sizes were determined by the method of Huffman et al. 12

Three different iron-oxide phases have been produced using the RTDS method including hematite, proto-goethite, and 6-line ferrihydrite. The crystallite size can be selected using this process by changing reaction conditions such as temperature. Lower processing temperatures yield smaller sized crystallites while higher temperatures yield larger particles. The Mossbauer spectroscopy, transmission electron microscopy, and X-ray powder diffraction results are all consistent with extremely small crystallites being produced.

The ultra-fine iron-oxide materials produced by MRM and RTDS processes were found to be selective catalyst precursors for carbon-carbon bond scission in tests with the model compound naphthyl bibenzylmethane. Selectivities of up to $98 \%$ with total conversions of up to $77 \%$ were obtained with some of the materials produced by both the RTDS and the MRM methods. The bond scission selectivity without catalyst varied from $20-60 \%$ with total conversion being less than $5 \%$.

Selected coal liquefaction results using the MRM- and RTDS-produced iron-containing materials as catalyst precursors are shown in Table II. The MRM produced non-stoichiometric iron sulfide showed a $10 \%$ increase in THF solubles over non-catalyzed runs with the Wyodak coal while a modest increase in pentane solubles was also demonstrated. Hematite produced by the RTDS method $(<20 \mathrm{~nm})$ showed a modest increase in THF solubles and pentane solubles with the Blind Canyon Seam coal. 
Table II

Selected Coal Liquefaction Results

\begin{tabular}{|c|c|c|c|c|}
\hline Coal & Catalyst & $\begin{array}{l}\text { Reaction } \\
\text { Temperature }\end{array}$ & $\%$ THF Solubles & $\%$ Pentane Solubles \\
\hline $\begin{array}{l}\text { Wyodak } \\
\text { Wyodak } \\
\text { Wyodak }\end{array}$ & $\begin{array}{c}\text { None } \\
\mathrm{Fe}_{2} \mathrm{~S}_{3} \mathrm{a} \\
\mathrm{Fe}_{2} \mathrm{O}_{3} \mathrm{~b}+\mathrm{S}\end{array}$ & $\begin{array}{l}400^{\circ} \mathrm{C} \\
400^{\circ} \mathrm{C} \\
400^{\circ} \mathrm{C}\end{array}$ & $\begin{array}{l}75 \\
85 \\
86\end{array}$ & $\begin{array}{l}26 \\
30 \\
36\end{array}$ \\
\hline $\begin{array}{l}\mathrm{BCS} \mathrm{c} \\
\mathrm{BCS}\end{array}$ & $\begin{array}{l}\text { None } \\
\mathrm{Fe}_{2} \mathrm{O}_{3} \mathrm{~b}+\mathrm{S}\end{array}$ & $\begin{array}{l}400^{\circ} \mathrm{C} \\
400^{\circ} \mathrm{C}\end{array}$ & $\begin{array}{l}79 \\
88\end{array}$ & $\begin{array}{l}27 \\
31\end{array}$ \\
\hline $\begin{array}{l}\text { BCS } \\
\text { BCS }\end{array}$ & $\begin{array}{c}\text { None } \\
\mathrm{Fe}_{2} \mathrm{O}_{3} \mathrm{~b}+\mathrm{S}\end{array}$ & $\begin{array}{l}345^{\circ} \mathrm{C} \\
345^{\circ} \mathrm{C}\end{array}$ & $\begin{array}{l}57 \\
62\end{array}$ & $\begin{array}{l}27 \\
34\end{array}$ \\
\hline
\end{tabular}

a) synthesized by MRM b) synthesized by RTDS c) Blind Canyon Seam

\section{Summary}

Two new particle production methods are being developed at Pacific Northwest Laboratory which can produce multi-gram quantities of ultra-fine monodisperse iron-containing catalysts and catalyst precursors. The materials produced by these methods show excellent carbon-carbon bond scission selectivity and also promote coal liquefaction. Current effort is underway to scale up the RTDS process to produce $2 \mathrm{~kg}$ of fine particles per hour.

\section{Acknowledgements}

This work was supported by the U.S. Department of Energy, Office of Fossil Energy under contract DE-AC06-76RLO 1830 and by the Advanced Processing and Technology Initiative.

\section{References}

1. Pacific Northwest Laboratory is operated for the U.S. Department of Energy by Battelle Memorial Institute.

2. Pradhan, V.R.; Tierney, J. W.; Wender, I.; and Huffman, G. P., Energy \& Fuels, 1991, 5, 497.

3. Pradhan, V.R.; Herrick, D.E.; Tierney, J.W.; and Wender, I., Energy \& Fuels, 1991, 5, 712.

4. Suzuki, T.; Yamada, H.; Yunoki, K. and Yamaguchi, H., in Proceedings: 1991 International Conference on Coal Science. Newcastle on the Tyne, UK, 1991, 703.

5. Miki, K.; Yamamoto, Y.; Inabe, A.; and Sato, Y., in Proceedings: 1991 International

Conference on Coal Science. Newcastle on the Tyne, UK, 1991, 675.

6. Bi, X-X; Derbyshire, F.J.; Eklund, P.C.; Hager, G.T.; and Stencel, J. M., Energy \& Fuels, 1991, 5, 683.

7. Yokoyama, S.; Yamamoto, M.; Yoshida, R.; Maekewa, Y., Fuel, 1991, 70,163.

8. Linehan, J.C.; Bean, R.M.; Matson, D.W.; Fulton, J.L.; and Crump, A.E., in preprints, Div.

of Fuel Chem.., American Chemical Society, 1992, 37, 488.

9. Matson, D.W.; Linehan, J.C.; and Bean, R.M., Mateirals Letters, in press.

10. Farcasiu, M. and Smith, C., Energy \& Fuels, 1991, 5, 83.

11. Schertmann, U and Cornell, R.M., eds "Iron Oxides in the Laboratory", VCH, Weinheim, FRG, 1991.

12. Huffman, G.P.; Ganguly, B.; Taghiei, M.; Higgins, F.E.; and Shah, N., in preprints Div. of Fuel Chem., American Chemical Society, 1991, 36, 561. 
DATE

FILMED

215193 
